\title{
ASSESSING SOCIAL VULNERABILITY TO NATURAL HAZARDS IN NOVA FRIBURGO, RIO DE JANEIRO MOUNTAIN REGION, BRAZIL
}

\author{
Claudia Paola Cardozo ${ }^{1, *}$ and Antônio Miguel Vieira Monteiro ${ }^{1}$
}

\begin{abstract}
Brazil faces a complex scenario of natural hazards, essentially as a direct result of its size, diversity and both its natural and social heterogeneity. In 2011, massive landslides were triggered by extreme rainfall that caused the so-called "Mega disaster" in the mountainous region of Rio de Janeiro. This paper describes the development of a social vulnerability index at the census tract level using SoVI method. It also examines the potential value of the Social Vulnerability Index to explain the impact of the 2011 landslides on population of Nova Friburgo municipality. Principal Component analysis reveals that six factors explain $73.6 \%$ of the data variance. Spatial pattern analysis suggests that about $84 \%$ of the area is classified with moderate level of social vulnerability. The highest social vulnerability values are concentrated in areas where population density is high and the main economic activities are developed. The resulting knowledge provides to local community, government and civil organizations with a basis to comprehend the geography and drivers of social vulnerability, which can be leveraged to achieve an effective preparation and response to face future natural hazards and also to promote disaster-resilient societies.
\end{abstract}

\section{KEYWORDS}

Social vulnerability, Natural hazards, Principal Component Analysis, Brazil

\section{EVALUACIÓN DE LA VULNERABILIDAD SOCIAL A LOS PELIGROS NATURALES EN NOVA FRIBURGO, REGIÓN MONTAÑOSA DE RIO DE JANEIRO}

\section{RESUMEN}

Brasil enfrenta un escenario complejo de peligros naturales, como resultado directo de su tamaño, diversidad y heterogeneidad tanto social como natural. En 2011, se produjeron deslizamientos masivos provocados por lluvias extremas que causaron el denominado "Megadesastre" en la región montañosa de Rio de Janeiro. Este trabajo describe el desarrollo de un Índice de Vulnerabilidad Social a nivel de distrito censal, utilizando el método SoVl. También examina el valor potencial del índice para explicar el impacto de los deslizamientos de 2011 en la población de Nova Friburgo. El Análisis de Componentes Principales (ACP) revela que seis factores explican el 73.6\% de la varianza de los datos. El análisis de patrones espaciales sugiere que aproximadamente el $84 \%$ del área es clasificada con nivel moderado de vulnerabilidad social. Los valores más altos se registran donde la densidad de población es alta y además se desarrollan las principales actividades económicas. El conocimiento resultante proporciona a la comunidad local, al gobierno y a las organizaciones civiles una base para comprender la geografía y los impulsores de la vulnerabilidad social, que pueden aprovecharse para lograr una preparación y respuesta efectivas para enfrentar futuros peligros naturales y también para promover sociedades resilientes a los desastres.

\section{PALABRAS CLAVE}

Vulnerabilidad Social, Peligros Naturales, Análisis de Componentes Principales, Brasil
1. National Institute for Space Research, São Paulo, Brazil.

*Corresponding author paola.cardozo.del@ gmail.com

\section{RECEIVED}

26 April 2019

\section{ACCEPTED}

26 June 2019

PUBLISHED

1 July 2019

Recommended citation (APA style):

Cardozo, C.P. \& Monteiro, A.M.V. (2019). Assessing social vulnerability to natural hazards in Nova Friburgo, Rio de Janeiro Mountain Region, Brazil. Revista de Estudios Latinoamericanos sobre Reducción del Riesgo de Desastres REDER, $3(2)$, 71-83.

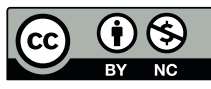

All articles published in REDER follow an Open Access policy and are supported by a CreativeCommons Attribution-NonCommercial 4.o International License.

Journal of Latin American Studies on Disaster Risk Reduction (REDER)

Revista de Estudios Latinoamericanos sobre Reducción del Riesgo de Desastres (REDER)

Design: Lupe Bezzina Typography: Hospital 


\section{INTRODUCTION}

Fatalities and economic losses due to natural hazards have shown an increase over the past decades, caused by the increase of number of weather-related events but also due to the increased global society vulnerability (Van Westen, 2000; Van Westen, 2013).

Brazil with a little bit than 190 million people (IBGE, 2010) presents a complex scenario of threats, essentially as a direct result of its size, diversity and both its natural and social heterogeneity. Between 1900-2013 there were around 150 disaster records triggered by natural events, whose associated impacts were also alarming: 10,052 casualties, 71 million people affected and a loss of about US $\$ 16$ billion (Camarinha et al., 2014). Brazilian authorities recognized the unpreparedness to face natural hazards and its effects. Limitations in financial resource availability and operative capacity to planning, monitoring and control of human settlements were accepted (Busch \& Amorim, 2011).

In the mountains called locally as "Serra do mar", which extends for about 2,500 km, destructive landslides result in serious economic losses and cause a great social impact. Landslides were recorded in São Paulo in 1985 (Nery \& Vieira, 2014), in Rio de Janeiro in 1966, 1967, 1988, 1996 and 2010 (Avelar et al., 2011) and particularly in Nova Friburgo municipality in 1924, 1940, 1977, 1979, 2007, 2011 (DRM-RJ, 2015)

On January $11-12^{\text {th }}, 2011$ massive landslides were triggered by extreme rainfall conditions, generating the so-called "Mega disaster" in the mountainous region of Rio de Janeiro. Twentythree municipalities were reached, from these, seven were stated in public calamity situation: Areal, Bom Jardim, Nova Friburgo, São José do Vale do Rio Preto, Sumidouro, Petrópolis and Teresópolis (Vassoler, 2013). This event is considered the worst disaster in Brazilian history (Castilho et al., 2012), not only because of the human fatalities that it caused, but also because of the significant losses and economic damage with negative implications on the survivor's life quality and on the entire region economic activity (World Bank, 2012). Whole areas were covered by mud, hundreds of homes were swept away and hundreds of people were buried. Nova Friburgo, Teresópolis and Petrópolis municipalities recorded the greatest number of casualties. In Nova Friburgo, the greatest impact occurred within the urban area, while the rural outskirts were the most affected in the others cities (Busch \& Amorim, 2011). Official numbers indicated 918 casualties; 22,604 displaced and 8,795 homeless (Freitas et al., 2012); however, civil associations point out that the number of fatalities and missing people could be ten times greater. The divergence in numbers can be attributed, in part, to the fact that entire families disappeared and no one claimed for them.

The vulnerability concept has emerged from notion of everyday language to a more elaborated concept. Traditionally, there was a tendency to use it independently from context, nevertheless vulnerability is both context-dependant and subject-dependant (Nathan, 2005). Although there is no universal vulnerability definition, various disciplines have developed their own definitions (Birkmann, 2006). Several authors have recognized the multifaceted nature of the vulnerability (Fuchs, 2009; Parker et al., 2009; Tapsell et al., 2010; Van Westen et al., 2011; Menoni et al., 2012). Physical, economic, institutional and social dimensions, among others are recognized as main aspects of vulnerability.

Conceptual models of vulnerability serve to identify the risk components and to choice the appropriate indicators of vulnerability (Roberts et al., 2007). Conceptual frameworks on vulnerability were proposed over the time by different schools of thinking, such as: i) The Double Structure of Vulnerability (Chambers, 1989; Bohle, 2001); ii) the Pressure and Release Model (PAR Model) (Blaikie et al., 1994; Wisner et al., 2004); iii) the BBC framework (Bogardi \& Birkmann, 2004; Cardona, 1999); iv) the Risk-Hazard (RH) Model (Turner et al., 2003). A good overview is given by Birckmann (2006)

According to Tapsell et al., (2010) social vulnerability in itself can be also treated as a multifaceted entity. It can be characterized by attributes on a scale more closely focused on the social aspects, such as livelihood, housing, income, education, security and gender among many others. Social vulnerability assessment is now recognized as critical to understanding natural hazard risks and for developing effective response capabilities (Wisner et al., 2004). Qualitative and quantitative approaches have been used to describe social vulnerability. One of the most known approaches is the Social Vulnerability Index (SoVI) proposed by Cutter et al., (2003). This methodology serves to identify and classify social vulnerability using census data (Cutter \& Morath, 
2013; Willis \& Fitton, 2016; Wisner, 2016) making possible to identify the key vulnerability drivers across the territory (Cutter \& Finch, 2008).

Understanding disaster risk is a priority area of the Sendai Framework 2015-2030 for Disaster Risk Reduction (UNISDR, 2015). This paper, addresses an important subcomponent of disaster risk equation -social vulnerability- in the Brazilian municipality of Nova Friburgo. In addition, the potential value of the Social Vulnerability Index to explain the impact of the 2011 landslides on local populations is examined.

This article is organized as follows. Section 2 describes the study area. In Section 3 the materials and methods used in this research are detailed. Section 4 presents and discusses the results. Finally, section 5 summarizes the key findings.

\section{STUDY AREA}

Nova Friburgo municipality is located in the Rio de Janeiro State mountainous region, Brazil (see Figure 1). It has approximately $934 \mathrm{~km}^{2}$ and is situated in the "Serra dos Órgãos", a local name that designates a higher portion of the mountains called "Serra do Mar". The elevation ranges from 636 to 1587 meters above sea level. The zone has a predominantly high-altitude tropical climate with an average temperature of $16^{\circ} \mathrm{C}$. This area was originally covered by Tropical Atlantic Rainforest, but currently is fragmented and much degraded, especially around urban areas. Nova Friburgo is the highest rainfall zone in the State with an average annual precipitation of about $2500 \mathrm{~mm}$ in the highest areas, decreasing progressively to $1300 \mathrm{~mm}$ to the north (Coelho Netto et al., 2011).

In 2010, one year before the massive landslide event, Nova Friburgo reached a population of 182,082 inhabitants (195 inhabitants per square kilometer). About $90 \%$ of the inhabitants lived mainly in the urban zones (IBGE, 2010) when the disaster struck.

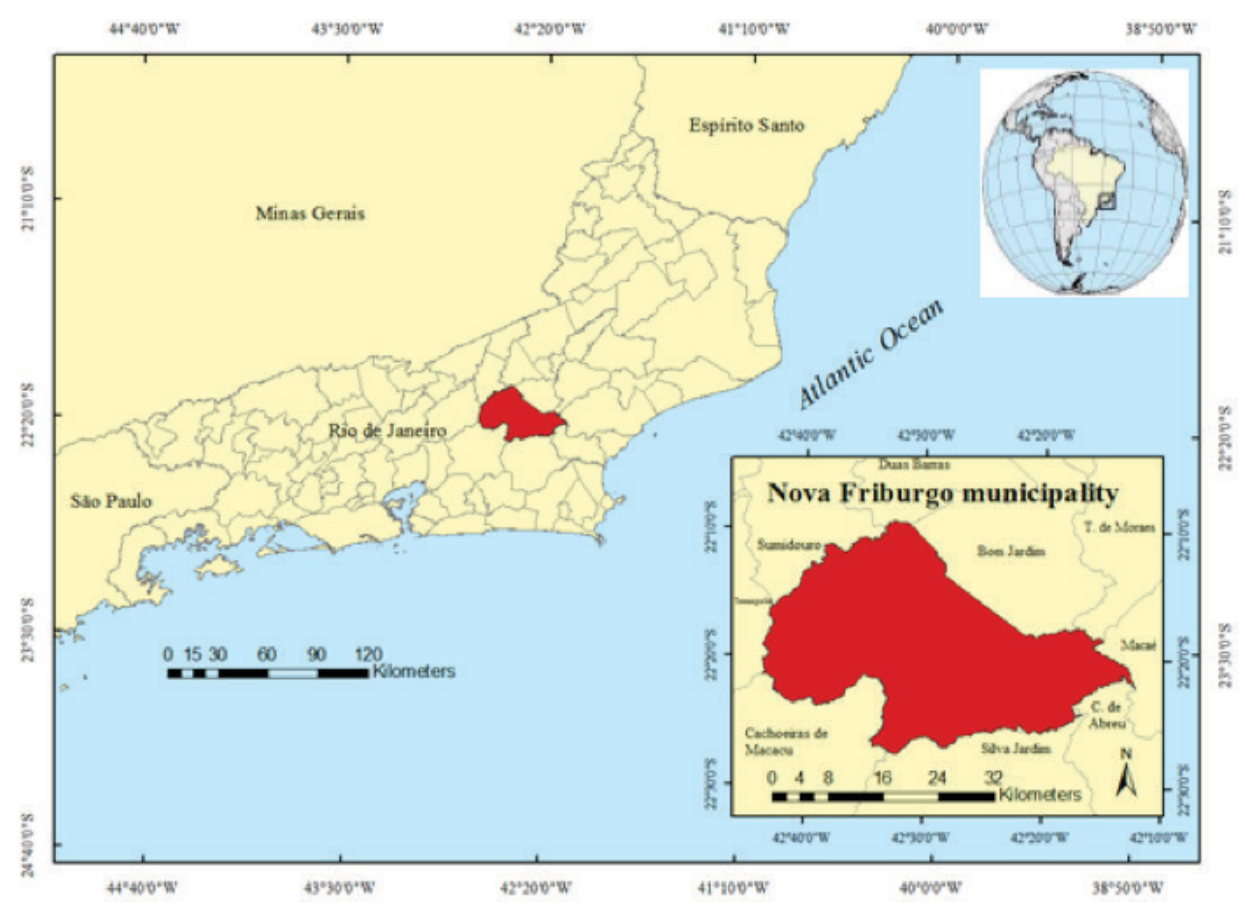

Figure 1. Localization of the Nova Friburgo municipality, Rio de Janeiro State, Brazil Source: Authors, 2019.

\section{MATERIALS AND METHODS}

The social vulnerability assessment is based on the Social Vulnerability Index (SoVI) proposed by Cutter et al., (2003). Data used in the analyses were obtained from the 2010 Census provided by the Brazilian Institute of Geography and Statistics (IBGE)1. The census variables, originally added in census tracts, were chosen according to: i) the available data according to the concepts and metrics of the original method and; ii) their relevance to the Nova Friburgo municipality's context.

Because the original SoVI method was conducted at country level, it was necessary customize the Social Vulnerability Index incorporating features with the potential to better describe the 
socio-economic reality at more fine grained spatial scale. For this purpose, the indicators "Socioeconomic status" and "Quality of the built environment" were adapted. Table 1 shows the social vulnerability concepts, census variables and metrics used to calculate the SoVI index for Nova Friburgo.

The Socio-economic status concept represents the ability to absorb losses and enhance resilience to natural hazard impacts. When a natural hazard strikes, all the people could be affected to a greater or lesser extent, however wealth enables high-income communities to face disasters absorbing and recovering from losses more quickly due to insurance, social safety nets and entitlement programs (Cutter et al., 2003). Household monthly income per capita and tenure class housing (owner, renter or rent-free household) were used to build this indicator. According to IBGE (2010), the minimum income was equal to US\$300 (equal to 510 reais, real is the Brazil national currency) in 2010.

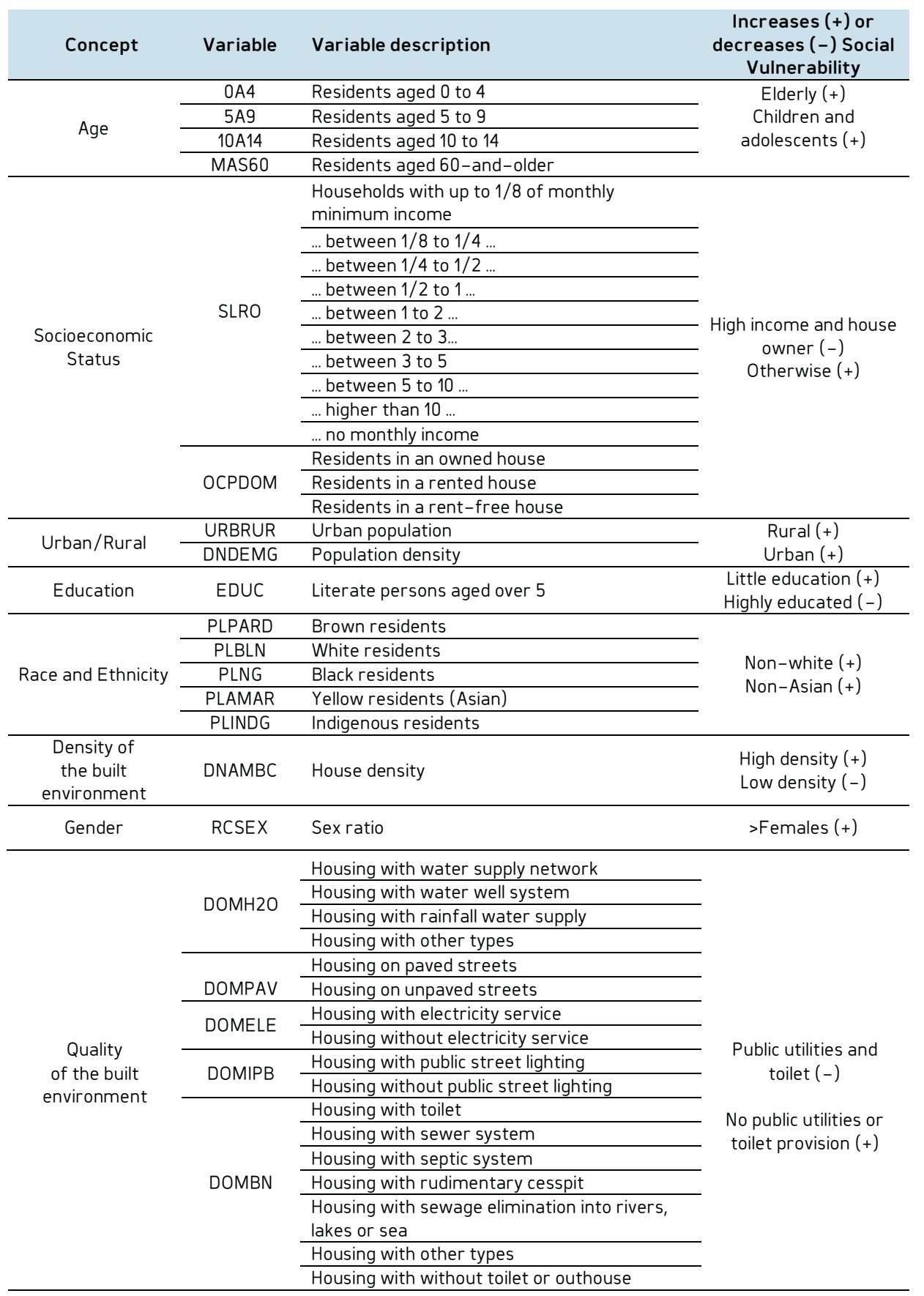

Table 1. Census variables used in the Social Vulnerability Index Source: Authors, 2019. 
Infrastructure is a key element of poverty alleviation and vulnerability. It often acts as a catalyst to development and enhances the impact of interventions to improve the most vulnerable's access to other assets, e.g., human, social, financial, and natural assets. Its impact is felt both on the economic and social sectors (World Bank, 2000). The Quality of the built environment concept relates to the availability of water supply, paving, electricity and Public Street lighting. In addition, it takes into account toilet availability by household and different ways of sewage disposal.

The Race and ethnicity concept corresponds to "colour or race" census variables, i.e., white, black, brown (locally named "pardo"), yellow (Asian) and indigenous residents. The average monthly income for the White and Asian populations is about twice as high as that of the others (IBGE, 2011). Cutter et al., (2003) points out that race and ethnicity imposes language and cultural barriers that affect access to post-disaster funding and leave certain groups in residential locations in high hazard areas. However in the Brazilian case, the barriers are mainly posed because there is a close relationship between skin colour and the socio-economic condition. Race discrimination is the mechanism that historically hinders the inclusion of black population.

Extreme age groups are the most affected in disasters (Cutter et al., 2003). It is well known that children are not autonomous but dependent on others. Similarly, the elderly may have physical limitations that influence their inability or unwillingness to comply with mandatory evacuation orders (Cutter \& Finch, 2008). In brief, they are less able to get out of the damage area on their own. Taking into account these premises and social context of Nova Friburgo, the Age concept includes children, adolescents and the elderly as vulnerable groups.

The Gender concept corresponds to the ratio of males to females. According to Cutter et al., (2003), women can have a more difficult time during disaster recovery than men, often due to sector-specific employment, lower wages and family care responsibilities. In the Brazilian context, gender discrimination can obstruct the inclusion of women in disaster recovery.

The spatial patterns in Brazilian cities are explained by the great migration from rural areas to urban centers due to growing industrialization (Hummell et al., 2016). Since 1970, more than 40 million Brazilians have migrated from rural to urban areas (Gonçalves, 2001). Both rural and urban communities face challenges when hazard strikes. Rural residents may be more vulnerable due to lower income while high-density areas (urban) complicate evacuation out of affected area (Cutter et al., 2003). The Urban/Rural concept includes population density and urban population percentage variables, following Hummell et al., (2016).

The Education concept corresponds to the number of literate persons aged 5 on. According to Cutter et al. (2003), higher educational attainment results in greater lifetime earnings. On the contrary, lower education constrains the ability to understand warning information and access to recovery information.

The Density of the built environment concept involves the human-made surroundings that provide the setting for human activity where significant structural losses might be expected derived from natural hazard occurrence and also with longer-term issues related to the recovery.

Fourty-four census variables used to examine the social vulnerability were previously normalized to percentages, natural logarithm and normal probability density function. Additionally, with the aim to perform subsequent multivariate analysis, we standardise them into a homogenous format by using the Range standardisation method. The standardised observation $(x n)$ was calculated as a ratio from the maximum and minimum observations for a given variable. This leads to all observation values being classified between 0 to 1 (Willis \& Fitton, 2016). In the case of multistratified variables, such as the "Socio-economic status" and "Quality of the built environment" an additional procedure was required. Both concepts were defined including the wide spectrum of information provided by the census while adopting an evolutionary scale to weigh each stratum of the variable following the methodology proposed by Anazawa, (2012) in which higher weigh represents best condition of the variable and lower weight means the worse one.

In order to provide a robust set of independent factors for the construction of the Social Vulnerability Index, a Principal Component Analysis (PCA) was performed using Varimax rotation with Kaiser Normalization (Kaiser, 1958). This technique reduces the original dataset dimension while retaining the variability as long as possible. The Kaiser criterion (eigenvalues $>1.00$ ) and sedimentation graph were used to selecting the final number of principal components. To determine 
whether the chosen variables were adequate for the statistical analyses, we used the Bartlett's sphericity test (Snedecor \& Cochran, 1989) and the Kaiser-Meyer-Olkim's measure (Cerny \& Kaiser, 1977). For interpretation purposes, most significant indicators (with correlations over 0.5 and lower than -0.5 ) were assumed as drivers of each component and provided the rationale for cardinality $( \pm)$ according to their influence on social vulnerability. The overall influence of factors on social vulnerability was determined based on positive values that indicated higher levels of vulnerability, while negative ones indicated lower levels (Hummell et al., 2016). Social Vulnerability Indicator was then calculated by assuming an additive model with equal weights for each principal component. To identify the social vulnerability spatial distribution, the SoVI scores were mapped based on the Standard Deviation classification method, following the original approach. Finally, the social vulnerability spatial autocorrelation was assessed with the Global Moran's test (Moran, 1948). Local spatial clusters were also evaluated using the Local Indicators of Spatial Association (LISA) proposed by Anselin (1995).

\section{RESULTS AND DISCUSSION}

\section{Social Vulnerability in Nova Friburgo}

The Social Vulnerability Index (SoVI) is a relative measure of the social vulnerability (Cutter et al., 2003) for each of Nova Friburgo census tracts (see Figure 2).

SoVI scores range from -7.33 (lower social vulnerability) to 5.48 (highest social vulnerability). Census tracts with scores over 1.5 standard deviations are classified with very high social vulnerability, representing approximately $0.2 \%$ of the total area (in red). Likewise, about $1 \%$ of the territory is classified with high social vulnerability with index scores between 0.5 to 1.5 standard deviations (in orange). Although most socially vulnerable areas were not widely distributed in the territory, its importance lies in their location and implications for Nova Friburgo community's economic health. In fact, many census tracts of the two most populated districts which concentrate the main economic activities, such as "Conselheiro Paulino" and "Nova Friburgo" are located within these high social vulnerability areas. Most census tracts (83.9\%) show moderate levels of social vulnerability, with index scores between -1.5 to 0.5 standard deviations (in yellow). Over $8 \%$ of the census tracts represent low social vulnerability with SoVI scores between -2.5 to -1.5 standard deviations, mainly located in the southwestern border (in light green). On the other hand, 6.3\% of the area is classified with very low social vulnerability with index scores under -2.5 standard deviations, located in urban peripheral census tracts (in light blue).

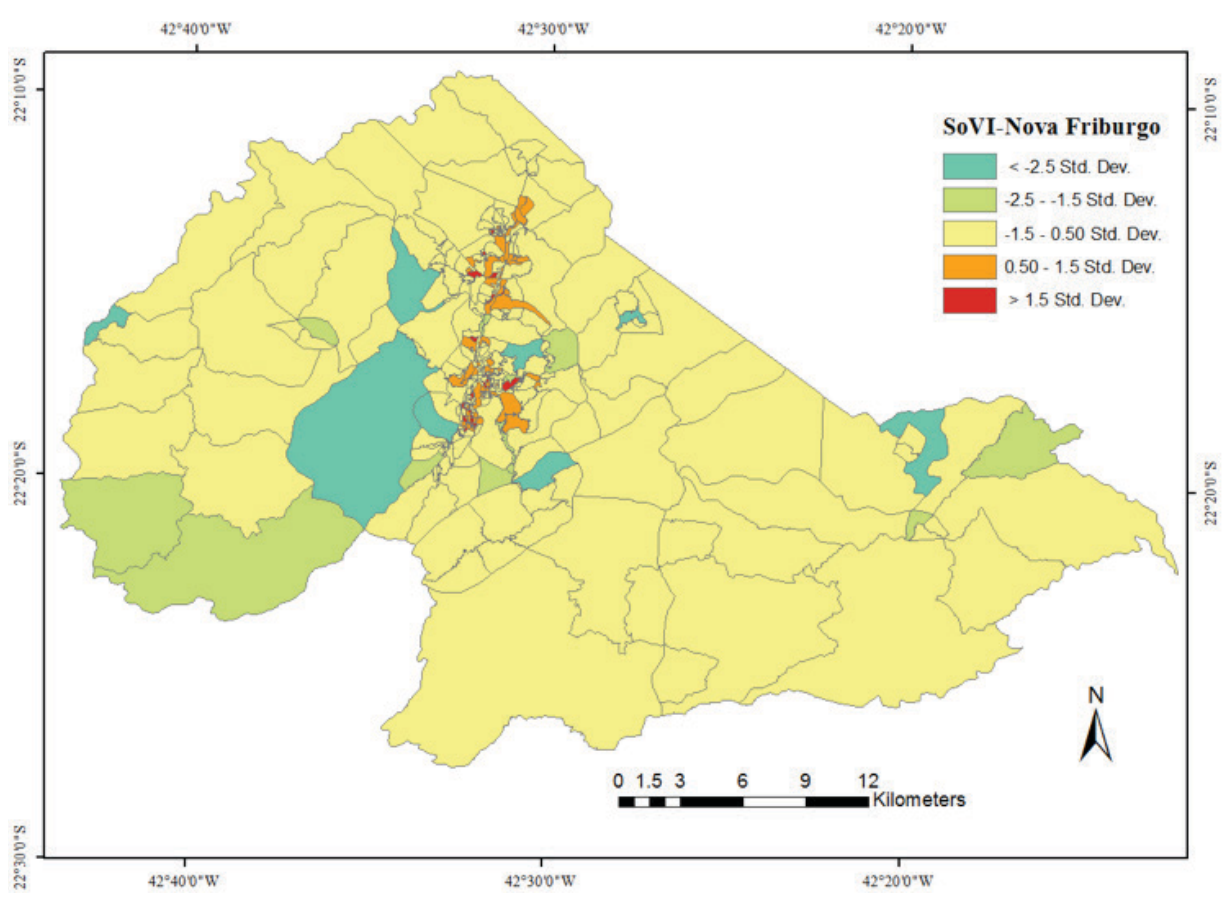

Figure 2. Geographic pattern of Social Vulnerability at the Nova Friburgo municipality Source: Authors, 2019. 
Comparing social vulnerability geography outcomes with previous works in the region, such as Costa \& Marguti, (2015) and Hummell et al., (2016), who used social vulnerability indicators at municipality and city-level respectively, we note differences. Both studies identify low social vulnerability for the Nova Friburgo area, while we determine moderate local-level social vulnerability with hot-spots of high and very high social vulnerability. We interpret this result as an evidence of the importance of measuring social vulnerability at sub-national geography levels customizing indices to improve understanding of social vulnerability at more fine grained spatial scales. According to Turner et al., (2003) vulnerability analysis usefulness increases when it is capable of providing vulnerability understanding of a particular place.

\section{Factors influencing Social Vulnerability}

Principal Components Analysis (PCA) reveals that six factors explain $73.6 \%$ of the data variance (eigenvalues > 1.00) (see Figure 3; Table 2).

Figure 4 shows the spatial distribution of the Social Vulnerability Index in each Factor or Principal Component.

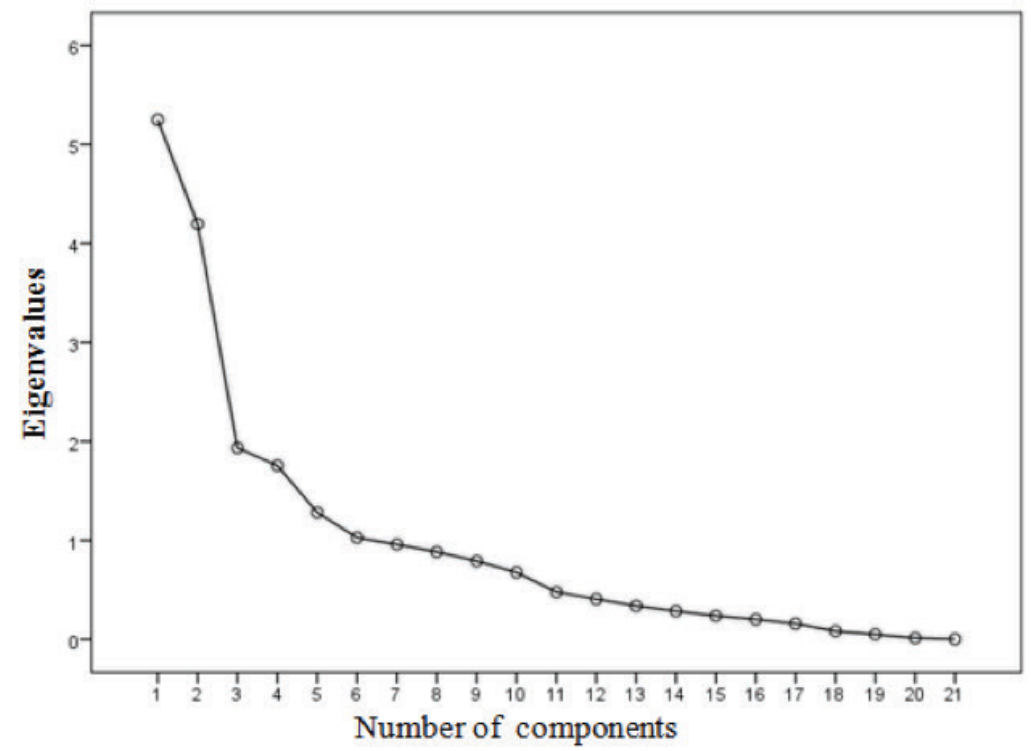

Figure 3. Sedimentation graph derived from Principal Component Analysis (PCA) Source: Authors, 2019.

\begin{tabular}{|c|c|c|c|}
\hline Component & $\%$ & Involved concepts & Drivers (Factor correlation) \\
\hline \multirow{7}{*}{ PC1 } & \multirow{7}{*}{25} & \multirow{7}{*}{$\begin{array}{l}\text { Urban/Rural } \\
\text { Quality of the built environment } \\
\text { Density of the built environment }\end{array}$} & URBRUR (0.87) \\
\hline & & & DOMPAV (0.86) \\
\hline & & & DNAMBC (0.83) \\
\hline & & & DNDEMG (0.83) \\
\hline & & & DOMH2O (0.81) \\
\hline & & & DOMBN (0.55) \\
\hline & & & DOMELE (0.50) \\
\hline \multirow{4}{*}{ PC2 } & \multirow{4}{*}{20} & Race and Ethnicity & PLBLN (0.89) \\
\hline & & Education & EDUC (0.88) \\
\hline & & Age & MAS60 (0.87) \\
\hline & & Socio-economic Status & OCPDOM (0.50) \\
\hline \multirow{3}{*}{ PC3 } & \multirow{3}{*}{9.2} & \multirow{3}{*}{$\begin{array}{l}\text { Race and Ethnicity } \\
\text { Age }\end{array}$} & PLPARD (0.90) \\
\hline & & & $10 \mathrm{~A} 14(0.90)$ \\
\hline & & & OA4 (0.88) \\
\hline \multirow{4}{*}{ PC4 } & \multirow{4}{*}{8.4} & Race and Ethnicity & PLNG (0.86) \\
\hline & & Socio-economic Status & SLRO $(-0.83)$ \\
\hline & & Age & $5 \mathrm{A9}(0.70)$ \\
\hline & & Gender & RCSEX (0.55) \\
\hline PC5 & 6.1 & Quality of the built environment & DOMIPB (0.87) \\
\hline PC6 & 4.9 & Race and Ethnicity & PLAMAR (0.78) \\
\hline
\end{tabular}

Table 2. Components, explained variance percentage, major drivers and involved concepts Source: Authors, 2019 
The first principal component (PC1) explains $25 \%$ of the variance and identifies drivers related to Urban/Rural, Quality of the built environment and, Density of the built environment. All of them, loaded positively, indicating higher values of social vulnerability. This factor reveals zones with very high social vulnerability concentrated in the municipality center, where the population urban density is higher with a high household density too (see Figure 4A). According to Hummell et al., (2016) a large population in the same area suggests not only that more people might be affected by a disaster, but also might have more difficulty in an eventual evacuation or rescue situation which make them more vulnerable to the natural hazards. Similarly, south and southeast peripheral urban areas show high social vulnerability probably related to the lack of access to water, sewage, electricity and paving. These findings are in agreement with Carmo et al., (2014) who point out that Brazilian urbanization process has not been accompanied by infrastructure and public service investments in all the country, which is translated into social inequality.

The second factor (PC2) explains $20 \%$ of the variance. A great deal of the municipality shows moderate social vulnerability and hot-spots of very high and high social vulnerability (see Figure 4B). In 2010, the municipal Human Development Index (HDI) was equal to 0.745 , among the highest in the country (IBGE, 2010). It is noteworthy that HDI components (income, education and longevity) agreed with the PC2 drivers, which factor correlation is over 0.8 (white residents, education and elderly over 60 ). This concordance might explain the moderate levels of vulnerability at Nova Friburgo. In this regard, according to the Elderly Statute (2003), elderly retirement salary increases family income among the poorest contributing to reducing poverty and vulnerability. Furthermore, census data reveals that $72 \%$ of population declared themselves to be white (IBGE, 2010) and historically in Brazil racial discrimination resulted in the white populations having higher income and education levels than both the black and brown ones (Campante et al., 2004).

Drivers describing the brown-skinned children and adolescents determine the third principal component (PC3) contributing to $9.2 \%$ of the overall variance. Although much of the area shows moderate social vulnerability (see Figure 4C), there also exist hot-spots of very high and high social vulnerability at the rural outskirts expressed by social inequality during infancy and adolescence. These findings can probably be explained, in part, by child labour. The 2010 census reveals that exist child labour at country level with more than 3 million children and adolescents aged 10 to 17 involved (IBGE, 2010). The Nova Friburgo municipality is no exception. Child labour is strongly linked to poverty and vulnerability. Need to work affects education access and permanence, so it ends up defining the income a person can earn throughout his/her life. Rural child labour is socially accepted and recurrent in Nova Friburgo. In fact, it is encouraged by both school and parents, mainly who are agricultural producers (Rigout et al., 2015)

The fourth factor explains $8.4 \%$ of the data variance. Moderate social vulnerability characterizes much of the territory. Nevertheless, several rural western border census tracts and some urban belonging to the centre show high social vulnerability levels (see Figure 4D). In 2010, sex ratio in Nova Friburgo was equal to 0.92 (IBGE, 2010). As in PC3 case, this factor highlights the presence of a vulnerable group: black children aged 5 to 9 , mainly girls. As mentioned above, due to racial discrimination non-white residents traditionally had difficulty to accessing education- and a well-paid job later. These outcomes are in agreement with Ashley and Ashley, (2008); Sharif et al., (2015) who suggest that age and gender influence human vulnerability to natural hazards. Results also stand out households' monthly income as a driver that decreases vulnerability in the rest of the area.

The fifth factor (PC5) explains $6.10 \%$ of the variance and is driven by the public lighting system variable (DOMIPB). This utility highlights not only an aspect of the built environment, but also points out the population living conditions. It is important in cities with high urbanization rates -as the Brazilian ones. Figure 4E shows that very high and high social vulnerability are widely distributed throughout the entire study area, including both urban and rural zones. Social inequality becomes evident in this factor suggested by the lack of infrastructure and public services. Public lighting system contributes to social and economic development by improving inhabitants' living standards. From the social point of view, it favours public space occupation with licit night activities (preventing crime) while from the economic point of view, it facilitates commerce and tourismactivities strongly developed in Nova Friburgo. It is well known that the public lighting system is normally disrupted when a natural hazard strike, however its availability is essential for postdisaster activities once it resumes. 
The sixth principal component (PC6) explains $4.9 \%$ of the variance and is driven by the Asian resident's variable. Between 2000 and 2010 there was a great expansion of the Asian population in Brazil. In ten years, the "yellow population" increased 177\% (IBGE, 2010). This growth was remarkably higher than that of other groups in all regions of the country (Ferreira, 2016). Figure 4F shows moderate social vulnerability in much of Nova Friburgo. We argue that probably it is linked to Asian population's monthly income, which is superior to that of the Black, Brown and Indigenous citizens' (IBGE, 2011). Cutter et al., (2003) also identified this racial group as an indicator of social vulnerability in USA. In Brazil, it seems that race and ethnicity diversity plays an important role in shaping social vulnerability. Hummell et al., (2016) identified that Indigenous and Black populations as drivers of social vulnerability at country level, whereas at Nova Friburgo municipality, the Asian population stands out.

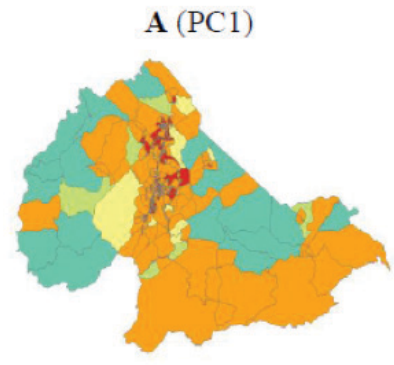

D (PC4)

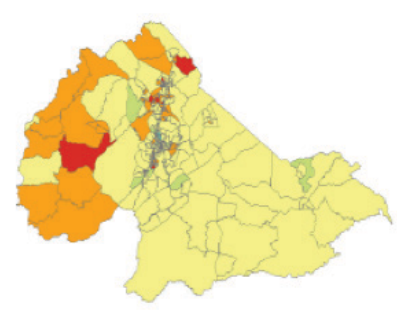

B (PC2)

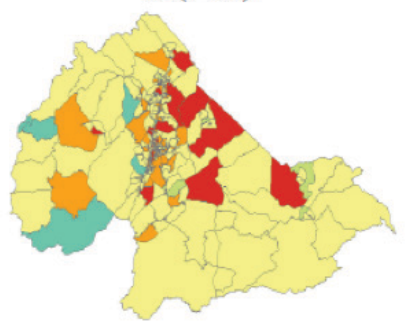

E (PC5)

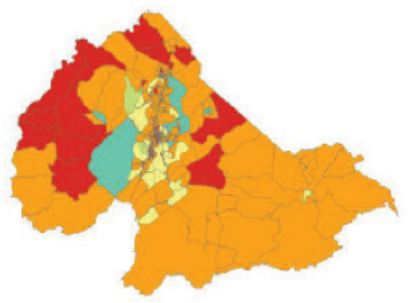

C (PC3)

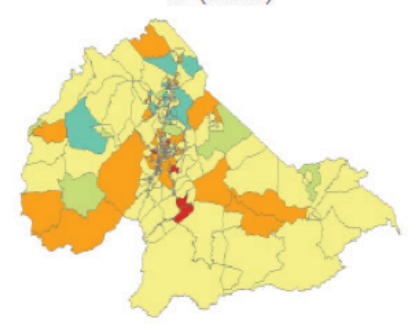

F (PC6)

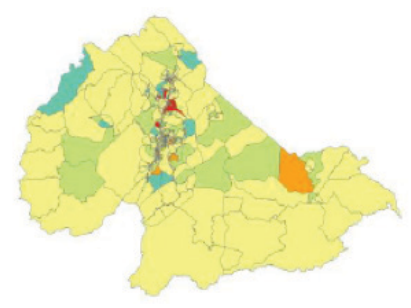

Social Vulnerability Levels (Standard Deviation)

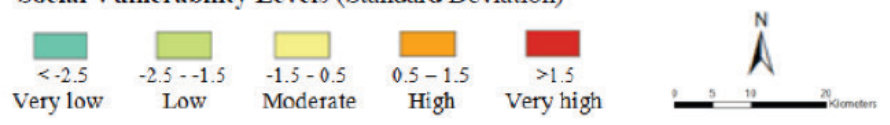

Figure 4. Geographic distribution of the Social Vulnerability Index in each Principal Component Figure 4. Geographic

\section{Spatial analysis of Social Vulnerability}

Data reveal that social vulnerability respond to a weak spatial aggregation pattern (Moran's $I=0.266, p<0.005$ ). Figure 5 shows that not all regions contribute equally to the global Moran's indicator. Red highlighted regions have high social vulnerability values as do neighbouring areas with high values (high-high), located at the municipality centre. Blue areas have both low social vulnerability and neighboring zones with low values (low-low), mainly located in the municipality western border. Approximately $0.65 \%$ of census tracts exhibit a combination of opposing values (low-high) and $9.94 \%$ high-low values. About, $71 \%$ of the census tracts do not present local spatial autocorrelation. The latter is in accordance with findings in city of São Paulo, Brazil (Roncancio \& Nardocci, 2016), showing lack of spatial autocorrelation in much of the territory when using the SoVI methodology at basin scale.

According to Gautam (2017), data constraint play an important role in social vulnerability assessment and results may vary according to the number of variables used. Although this research offers a sound social vulnerability measure, further tests including other variables should be carried out in order to analyze whether the inclusion of more variables might better describe the social reality of the Nova Friburgo municipality. 


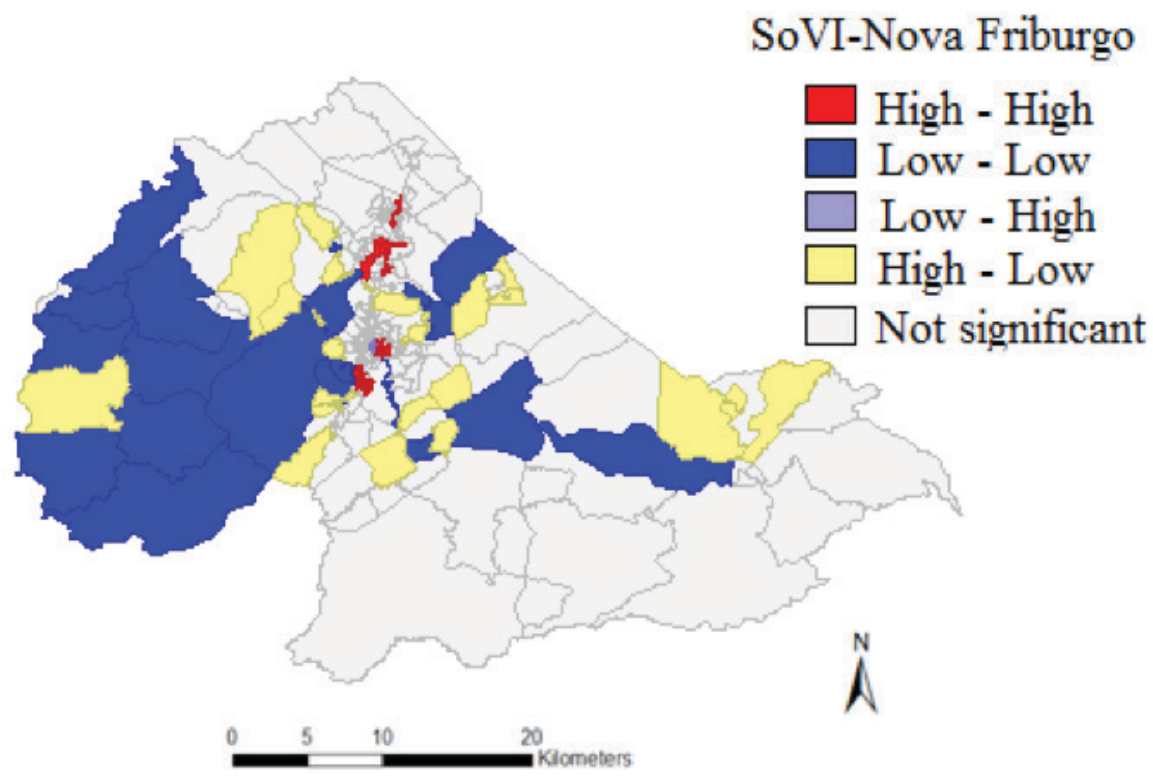

Figure 5. Lisa cluster map for Social Vulnerability Index with $p<0.005$ Source: Authors, 2019.

\section{Social Vulnerability and the $\mathbf{2 0 1 1}$ landslide-related fatalities}

A deep study about loss of life due to the 2011 landslides at the Nova Friburgo municipality revealed that cause of death for all the victims was mechanical asphyxia caused by burial. A total number of landslide-related deaths was 434 (205 women and 228 men) (Cardozo et al., 2017; 2018). This represents more than $47 \%$ of fatalities in the Mega-disaster occurred at the mountainous region of Rio de Janeiro.

In order to explore the social vulnerability index potential to explain the 2011 landslide-related fatalities we performed a Pearson's correlation analysis. A weak linear association $(r=-0.084$, $p>0.05$ ) suggest no discernible trend between both dataset. We argue that landslides' number, magnitude and spatial distribution were so great that all the Nova Friburgo inhabitants were equally affected, producing casualties in all social strata beyond the socio-economic inequality expressed by their social vulnerability. Additionally, environmental degradation and disorderly land occupation patterns might have exacerbated the landslides' impacts (Freitas et al., 2012).

Social vulnerability was probably most apparent after landslides, influencing the access to resources for structural reconstruction and but above all affecting the most vulnerables' capacity to face log-term recovery.

\section{CONCLUSION}

This article provides a social vulnerability assessment to natural hazards in the Nova Friburgo municipality, a zone prone to landslides. This study then helps to identify social vulnerability drivers and territories that are priorities for intervention with social policies which in turn can steer the development and implementation of disaster risk reduction strategies. We find that most of the territory shows moderate level of social vulnerability, however, areas high on vulnerability are important because of their location and implications for the municipality economic matrix and therefore, they need attention in regard to emergency planning and preparation. We sought to establish whether there was any linear association between social vulnerability and the 2011 landslide-related deaths. Data did not reveal a discernible trend. It seems that landslides' number, magnitude and spatial distribution were so great that all the Nova Friburgo inhabitants were equally impacted. In fact, fatalities occurred in all social strata. Social vulnerability was probably most apparent after landslide impact and the most vulnerable people could have encountered obstacles in recovery and reconstruction phase after disaster. We conclude that measuring social vulnerability at sub-national geography levels with customized indices might improve understanding of social vulnerability at more fine grained spatial scales. Additionally, it can help emergency planners and authorities in improving communities' overall ability to face future natural hazards. 
While the SoVI method has been used widely worldwide and has been recognized by the quality and detail of social vulnerability information it provides, the technique presents some challenges for public planning. Mainly due to the complexity of developing the index and also interpretation is not easy to explain to non-technical users.

\section{ACKNOWLEDGMENTS}

We would like to thank the Coordination for the Improvement of Higher Education Personnel (CAPES) - Brazil for the research financial support.

\section{REFERENCES}

Anazawa, T., Feitosa, F. \& Monteiro, A. (2013). Vulnerabilidade socioecológica no litoral norte de São Paulo: medidas, superfícies e perfis de ativos. Revista Geografia, 38(1), 189-208.

Anselin, L. (1995). Local Indicators of Spatial Association - LISA. Geographical Analysis, 27(2), 93-115.

Ashley, S.T. \& Ashley, W. S. (2008). Flood fatalities in the United States. Journal of Applied Meteorology and Climatology, 47, 805-818.

Avelar, A.S., Coelho Netto, A.L., Lacerda, W.A., Becker, L.B. \& Mendonça, M.B. (2011). Mechanisms of the recent catastrophic landslides in the mountainous range of Rio de Janeiro, Brazil. In II World Landslide Forum. Rome: WLF.

Birkmann, J. (2006). Indicators and criteria for measuring vulnerability: theoretical basis and requirements. In Birkmann, J. (Ed.) Measuring vulnerability to natural hazards towards disaster resilient societies. Tokyo: United Nations University Press.

Blaikie, P., Cannon, T., Davis, I. \& Wisner, B. (1994). At risk: natural hazards, people's vulnerability and disasters. London: Routledge.

Bogardi, J. \& Birkmann, J. (2004). Vulnerability assessment: The first step towards Sustainable Risk Reduction. In Malzahn, D. \& Plapp, T (Eds). Disaster and Society: from Hazard assessment to Risk reduction. Berlin: Logos Verlag Berlin, pp. 75-82.

Bohle, H.G. (2001). Vulnerability and Criticality: Perspectives from Social Geography. Newsletter of the International Human Dimensions Programme on Global Environmental Change, 2, 1-7.

Busch, A. \& Amorim, S. (2011). A tragédia da Região Serrana do Rio de Janeiro em 2011: procurando respostas. ENAP-Casoteca de Gestão Pública, 328(1), 1-20.

Camarinha, P.I., Canavasi, V. \& Alvalá, S. (2014). Shallow landslide prediction and analysis with risk assessment using a spatial model in a coastal region in the State of São Paulo, Brazil. Natural Hazards and Earth System Science, 14, 2449-2468.

Campante, F.R., Crespo, A.R. \& Leite, G.P. (2004). Desigualdade salarial entre raças no mercado de trabalho urbano brasileiro: aspectos regionais. Revista Brasileira de Economia, 58(2), 185-210.

Cardona, O.D. (1999). Environmental management and disaster prevention: two related topics: a holistic risk assessment and management approach. In Ingleton, J. (Ed.) Natural Disaster Management. London: Tudor Rose.

Cardozo, C.P., Monteiro, A.M.V., Freitas, C.M. \& Lopes, E. S. (2017). Intra- urban differentials in the exposition and vulnerability to landslides: the Human Fatalities in the 2011 Nova Friburgo - RJ disaster. In the Camaden (Ed.) First Brazilian Workshop on Assessment of Hazards, Vulnerability Exposure and Disaster Risk Reduction. São José dos Campos: Cemaden.

Cardozo, C.P., Lopes, E. S. \& Monteiro, A.M.V. (2018). Shallow landslide susceptibility assessment using SINMAP in Nova Friburgo (Rio de Janeiro, Brazil). Revista Brasileira de Cartografia, 7o(4), 1206-1230.

Carmo, R. L., Dagnino, R.S. \& Johansen, I. C. (2014). Transição demográfica e transição do consumo urbano de água no Brasil. Revista Brasileira de Estudos de População, 31(1), 169-19o.

Castilho, L.V., Oliveira, P. \& Fabriani, E.C. (2012). Análise de uma tragédia ambiental e a participação da população no equacionamento dos problemas de moradia: um estudo de caso da tragédia na Região Serrana do Rio de Janeiro. In VI National ANPASS Meeting. Belem: Universidade de Para.

Cerny, C.A. \& Kaiser, H.F. (1977). A study of a measure of sampling adequacy for factor-analytic correlation matrices. Multivariate Behavioral Research, 12(1), 43-47.

Chambers, R. (1989). Vulnerability: How the poor cope. IDS Bulletin, 20(2), 1-7.

Coelho Netto, A. L., Sato, A. M., Avelar, A. S., Vianna, L. G., Araújo, I. S., Ferreira, D. L., Lima, P.H., Silva, A. P. \& Silva, R. (2011). January 20o1: The extreme landslide disaster in Brazil. In II World Landslide Forum. Rome: WLF. 
Costa, M.A. \& Marguti B. (Eds.). (2015). Atlas da Vulnerabilidade Social nos municípios brasileiros. Brasília: Instituto de Pesquisa Econômica Aplicada IPEA. Brasilia: IPEA.

Cutter, S.L., Boruff, B.J. \& Shirley, W.L. (2003). Social vulnerability to environmental hazards. Social Science Quarterly, 84(2), 242-261.

Cutter S. L. \& Finch, C. (2008). Temporal and spatial changes in social vulnerability to natural hazards. Proceedings of the National Academy of Sciences of the United States of America, 105(7), 2301-2306.

Cutter, S.L. \& Morath, D.P. (2013). The evolution of the Social Vulnerability Index. In Birkmann, J. (Ed.). Measuring vulnerability to natural hazards. Bonn: United Nations University Press, pp. 304-321.

Presidência da República, Brasil. (2003). Elderly Statute. Law Nº 10.741. Presidência da República [web]. Available in: http://www.planalto.gov.br/ccivil_03/leis/2003/L10.741.htm [Accessed 25 Jun 2017].

Ferreira, G.S. (2016). Expansão da população asiática no Brasil e no Rio Grande do Sul (200o-2010). Boletim Geográfico do Rio Grande do Sul, 28, 124-139.

Freitas, C.M., Carvalho, M.L., Ximenes, E.F., Arraes, E. \& Gomes, J.O. (2012). Vulnerabilidade socioambiental, redução de riscos de desastres e construção da resiliência - lições do terremoto no Haiti e das chuvas fortes na Região Serrana, Brasil. Revista Ciência e Saúde Coletiva, 17(6), 1577-1586.

Fuchs, S. (2009). Susceptibility versus resilience to mountain hazards in Austria - paradigms of vulnerability revisited. Natural Hazards and Earth System Science, 9, 337-352.

Gautam, D. (2017). Assessment of social vulnerability to natural hazards in Nepal. Natural Hazards and Earth System Science, 17, 2313-2320.

Gonçalves, A.J. (2001). Migrações Internas: evoluções e desafios. Estudos Avançados, 15(43), 173-184.

Hummell, B.M., Cutter, S.L. \& Emrich, C.T. (2016). Social vulnerability to natural hazards in Brazil. International Journal of Disaster Risk Science, 7, 111-122.

Brazilian Institute of Geography \& Statistics IBGE. (2010). 2010 Census. IBGE [web]. Available in: http:// www.ibge.gov.br/home/estatistica/populacao/censo2010/default.shtm [Accessed 10 Mar. 2016].

Brazilian Institute of Geography \& Statistics IBGE. (2011). Press room November 19, 2011. Available in: http://saladeimprensa.ibge.gov.br/en/noticias?view=noticia\&id=1\&busca=1\&idnoticia=2019 [Accessed 11 Aug 2017].

Kaiser, H. (1958). The Varimax criterion for analytic rotation in factor analysis. Psychometrika, 23, 187-200.

Menoni, S., Molinari, D., Parker, D., Ballio, F. \& Tapsell, S. (2012). Assessing multifaceted vulnerability and resilience in order to design risk-mitigation strategies. Natural Hazards, 64(3), 2057-2082.

Moran, P. (1948). The interpretation of statistical maps. Journal of the Royal Statistical Society, Series B-Methodological, 10, 243-251.

Nathan, F. (2005). Vulnerabilities to natural hazard: Case study on landslide risk in La Paz. In Proceedings of the World International Studies Conference. Istambul: Bilgi University.

Nery, T.D. \& Vieira, B.C. (2014). Susceptibility to shallow landslides in a drainage basin in the Serra do Mar, São Paulo, Brazil, predicted using the SINMAP mathematical model. Bulletin of Engineering Geology Environment, 74(2), 369-378.

Parker, D. \& Tapsell, S. (2009). Relations between different types of social and economic vulnerability. EU Project "Enhancing resilience of communities and territories facing natural and na-tech hazards" (ENSURE). Final Report.

Rigout, F., Martin, C., Simioni, A.P., Martinho, J., Zackiewicz, M. \& Mansour, V. (2015). Diagnóstico municipal: Trabalho infantil em Nova Friburgo. São Paulo: Technical Report.

Departamento de Recursos Minerais - Rio de Janeiro DRM-RJ. (2015). Cartografia geotécnica de aptidão urbana Nova Friburgo. Escala 1:10.ooo. Rio de Janeiro: Geological Survey of the State of Rio de Janeiro Report.

Roberts N.J., Nadim, F. \& Kalsnes, B. (2007). Quantification of vulnerability to natural hazards. In ISGSR2007. First International Symposium on Geotechnical Safety E Risk. Shangai: Tongji University.

Roncancio, D.J. \& Nardocci, A.C. (2016). Social vulnerability to natural hazards in São Paulo, Brazil. Natural Hazards, 84, 1367-1383.

Sharif, H., Jackson, T., Hossain, M. \& Zane, D. (2015). Analysis of flood fatalities in Texas. Natural Hazards Review, 16(1), 1-8.

Snedecor, G.W. \& Cochran, W.G. (1989). Statistical methods. Iowa State University Press: Ames. 
Tapsell, S., McCarthy, S., Faulkner, H. \& Alexander, M. (2010). Social vulnerability and natural hazards. London: Middlesex University Press.

Turner, B.L., Kasperson, R.E., Matson, P.A., McCarthy, J.J., Corell, R.W., Christensen, L., Eckley, N., Kasperson, J.X., Luerse, A., Martello, M.L., Polsky, C., Pulsiph, A. \& Schiller, A. (2003). A framework for vulnerability analysis in sustainability science. Proceedings of the National Academy of Science of the United States of America, 100(14), 8074-8079.

United Nations International Strategy for Disaster Reduction UNISDR. (2015). Sendai Framework for Action 2015-2030. Geneva: UNISDR.

Van Westen, C.J. (2000). Remote sensing for natural disaster management. International Archives of Photogrammetry and Remote Sensing, 33(7), 1609-1617.

Van Westen, C.J., Alkema, D., Damen, M.C., Kerle, N. \& Kingma, N.C. (2011). Multi-hazard risk assessment. Tokyo: United Nations University Press.

Van Westen, C.J. (2013). Remote sensing and GIS for natural hazards assessment and disaster risk management. Treatise on Geomorphology, 3, 259-298.

Vassoler, R. (2013). Ações da vigilância epidemiológica nos desastres naturais. Experiência na Região Serrana em 2011. Technical Report.

Willis, I., \& Fitton, J. (2016). A review of multivariate social vulnerability methodologies: A case study of the River Parrett catchment, UK. Natural Hazards and Earth System Science, 16, 1387-1399.

Wisner, B. (2016). Vulnerability as concept, model, metric and tool. In Oxford Research Encyclopedia of Natural Hazard Science. New York: Oxford University Press.

Wisner, B., Blaikie, P.M., Cannon, T. \& Davis, I. (2004). At risk: natural hazards, people's vulnerability and disasters. London and New York: Routledge.

World Bank. (200o). Infrastructure and poverty. New York: World Bank.

World Bank. (2012). Avaliação de perdas e danos: inundações e deslizamentos na Região Serrana do Rio de Janeiro. New York: World Bank Technical Report. 